\title{
Governance/Administration Corner
}

\section{- Feature}

\section{Postcolonial Studies}

Seit den 1980er Jahren ist eine Renaissance der Forschung zu neuerer Kolonialgeschichte zu beobachten, die sich in zahlreichen Veröffentlichungen niederschlägt. Dabei wird mittlerweile zwischen neuerer Kolonialgeschichte und sogenannten Postcolonial Studies unterschieden, wobei der Versuch einer Begriffsklärung bislang nicht befriedigend abgeschlossen werden konnte. Der nachfolgende Kurzbeitrag greift den Begriff Postcolonialism auf und bettet ihn in die derzeitige Forschungsdiskussion ein.

\section{One swallow does not make a summer, or why the Arab Spring does not rule out postcolonialism}

Postcolonial discourses are en vogue within academia though a clear understanding of the meaning of 'postcolonialism' is still missing. For sure, colonialism contributed to a great deal on how the world is shaped today. European colonial powers played an important role in shaping the political, economic, social and cultural conditions of the people and countries that were under their rule. The arbitrary drawing of boundaries which separated local ethnic and cultural groups, the open policy of political, linguistic and religious acculturation and alienation, the severe drainage of natural resources and raw materials from colonized entities are considered as the instruments of colonialism and regarded as modern imperialistic tools, today. Edward Said laid the foundation for postcolonial studies in 1978. Building on Foucault's theory of the relation between power and knowledge, Said denounced disciplinary traditions of oriental studies for favoring a "subtle and persistent Eurocentric prejudice against Arabo-Islamic peoples and their culture" (Said, 1978). Following Said, Bhabha (1994) developed a discourse theory of postcolonialism. He argued that instead of seeing colonialism as something locked in the past, we should consider its histories and cultures as constantly manifest in the present, challenging us to transform our understanding of cross-cultural relations.

Postcolonial studies emerged and became an attractive field of study that influences considerably other academic fields such as political science and international relations. Reflecting on the Arab Spring which seems to have further enhanced the demand for postcolonial studies, Dabashi (2012) claims that the world we have hitherto known as "the Middle East" or "North Africa" or "the Arab and Muslim world", all part and parcel of a colonial geography we had inherited, is changing. We have now entered the phase of documenting in what particular terms that world is transcending itself, overcoming the mystified consciousness into which it was colonially cast and postcolonially fixated. He further states that "the term 'West is more meaningless today than ever before - it has lost its potency, and with it the notion, and the condition, we had code-named postcoloniality. The East, the West, the Oriental, the colonial, the postcolonial - they are no more". ${ }^{1}$

Dabashi's argument that the Arab Spring contributed to overcome the divide between colonialism and postcolonialism is interesting. But his celebration of the Arab Spring as the end of postcolonialism reminds sadly of the liberal triumphalism exhibited by Fukayama (1992) following the collapse of the Soviet Union. In his enthusiasm, Dabashi has overlooked the fact that the Arab revolution did not 'enflame' large parts of the postcolonial geographies like Sub Saharan Africa. Also, not all countries in the Arab world were successfully taken by the wave of the protest either. Second, postcolonialism articulates a discourse that goes beyond the simple aspect of postcolonial geography. Krishna (2008) argues that in a globalised world, postcolonial discourses help to articulate resistance to hegemony. Reducing postcolonialism to a geographical category is failing to recognize the inner evolution of postcolonial theory to make sense of the current interdependent context (Bhabha, 1994). Lastly it must be recognized that the Arab Spring is itself a project in progress that is facing uncertainty and risks of expropriation. A realistic perspective is rather to observe the process carefully and to better clarify that the revolution is not confiscated from the "heroes of the street". For that task, postcolonial theory may again be useful.

\section{- Literature}

Bhabha, H. (1994). The location of culture. London: Routledge.

Dabashi, H. (2012). The Arab spring: The end of postcolonialism. London: Zed.

Fukuyama, F. (1992). The end of history and the last man. New York: Free Press.

Krishna, S. (2008). Globalization and postcolonialism: Hegemony and resistance in the twenty-first century. New York: Roman and Littlefield Publ.

Said, E. (1978). Orientalism. London: Routledge.

\section{Links}

www.postcolonialstudiesassociation.co.uk

www.naps-online.org

http://osuusep.blogspot.de

www.sfps.ac.uk

Wilfried Zoungrana, Universität Erfurt, E-Mail: wilfried.zoungrana@uni-erfurt.de

Heike Grimm, Universität Erfurt, E-Mail: heike.grimm@uni-erfurt.de

1 Quotation taken from www.aljazeera.com [http://aje.me/JoD1Nd]. 